\title{
Place of Environmental Management in Ukraine in the System of Modeling Management of Sustainable Development of the Region
}

\author{
OKSANA ZAMAZII \\ Department of Accounting, \\ Auditing and Taxation, \\ Khmelnytsky National University 11, \\ Instytutska str. UKRAINE, \\ OLHA DUPLIAK \\ Department of Automated Systems and \\ Modelling in Economics, \\ Khmelnytsky National University 11, \\ Instytutska str. UKRAINE
}

\author{
KARPENKO VITALII \\ Department of Marketing and \\ Trade Entrepreneurship, \\ National University 11, \\ Instytutska str. UKRAINE
}

\author{
OKSANA PROSKUROVYCH \\ Department of Automated Systems and \\ Modelling in Economics, \\ Khmelnytsky National University 11, \\ Instytutska str. UKRAINE \\ ANDRII MAZARCHUK \\ Department of Automated Systems and \\ Modelling in Economics, \\ Khmelnytsky National University 11, \\ Instytutska str. UKRAINE
}

\begin{abstract}
The level of dependence of the ecological state and its management in the Khmelnytsky region of Ukraine on the welfare of the population of this region is analyzed. The relationship between the level of income of the population of the region and the level of motivation of the same population in the sorting of buildings using a systematic approach within the ecological and economic system. The shift of consumption by the population of the region from the non-food sector to the food sector causes not only a change in parity in the triangle "man - business entity - nature", but also proves the lack of public interest in sorting household waste. This level of social responsibility and motivation of the region's population will indicate non-compliance with the goals of sustainable development of the region. The model of dependence of need for sorting of waste on the level of income of the population offered by us in article confirms it. The forecast of income growth of the population of Khmelnytsky region makes it possible to make assumptions about the growing interest of the population in sorting household waste, which will ultimately contribute to the sustainable development of the region.

Key-Words: - sustainable development, environmental management, regional development, living standards, level of consumer waste, systems approach, forecast model
\end{abstract}

Received: December 22, 2020. Revised: March 31, 2021. Accepted: April 6, 2021. Published: April 12, 2021.

\section{Introduction}

Sustainable socio-economic development of the region is ensured by efficient and environmental activities of its economic entities, which implement their mission to meet public needs and, at the same time - through taxes to the budget - to create a financial basis for macroeconomic tasks, including social. However, modern economic conditions, characterized by high dynamics of market changes and unpredictability of not only economic but also social processes, put forward new requirements for the management of sustainable development of any region. The interaction of economic entities of the region with its environment should be aimed at avoiding the depletion or degradation of natural resources and ensuring the long-term quality of the environment. Under such conditions, environmental sustainability will help meet the needs of today's population without compromising the ability of future generations to meet their needs. Environmental aspects should be taken into account when modeling the management of sustainable 
development of the region, which would prevent the harmful effects of economic entities, and oblige them to comply with the requirements of nature and environmental complexes.

\section{Problem Formulation}

Much modern work is devoted to the problem of environmental management [1-8].

Most of the works consider various issues of state and regional governance. In particular, a strategic environmental assessment is conducted in the sector of urban development of the regions of Western countries, focusing on government regulation and management, analysis of the advantages and disadvantages of such management and evaluation [1]. In some other works, the analysis of ecological development of the region is carried out through the prism of business structures, in particular in the work of Czech researchers, the interaction between environmental, social and managerial indicators and economic indicators of corporate companies is considered [2]. Part of the work, examining in detail the economic development of their region, the sustainable development of the region sees in the promotion of tourism [3].

The research analyzes certain theoretical points and provides practical recommendations for improving environmental management in the regions through the prism of business entities[9-13]. Thus, the research mainly analyzes certain economic aspects of the region's development and provides practical recommendations for improving environmental management through the prism of business entities[14,15].

However, despite the significant number of publications, the issues of environmental management for the conditions of maintaining the sustainability of the region remain relevant. Every region of any country is unique - with its economic level of development, specific way of life, traditions and culture of the population, unique natural and recreational resources. Therefore, this will require not so much a unified method of managing the ecological condition of such a region, as the introduction of special, characteristic management methods to take into account all the above nuances.

Therefore, the aim of the article is to analyze the dependence of environmental management of the Khmelnytskyi region of Ukraine on the welfare of the population.

With the help of methods of modeling the income of the region's population in the future and the level of household waste in the region, it would be possible to demonstrate the level of social responsibility and motivation of the region's population for sustainable development of the region.

Khmelnytsky region is characterized by a number of specific features. First of all, this is the region where one of the largest wholesale and retail markets for industrial goods in the country is located. Thus, trade and light industry, which provides both the goods of the markets and the jobs of the population of the region, form the vast majority of the income of the population of the region. Due to this, the region is investmentattractive, which is characterized not only by a developed logistics system both between regions of the country and with foreign cranes, but also by strong innovative production that produces competitive products, mainly in light industry. This situation has allowed Khmelnytsky region, excluding regions with regional centers with a population of over a million, to occupy almost a leading position in terms of income among the country's regions similar in size and population [13]. These features of the region created the conditions for the opening of the only waste management center in Ukraine in Khmelnytsky. As part of the Smart Environment. Khmelnytskyi project, a separate division of the Spetskomuntrans utility company, Khmelnytskyi's first waste management center was opened at a landfill to teach residents how to sort and dispose of waste properly. According to the experience of highly developed countries, in particular, Sweden, where $99 \%$ of waste goes to recycling, the higher the level of income of the population, the more motivated it is to preserve the ecology of the region. and its sustainable development.

The methodological basis for the study of ecological and economic development of the Khmelnytskyi region and its sustainable development is a systematic approach that allows combining diverse structural elements that interact with each other within the ecological and economic system.

We focused on the use of methods of linear modeling and forecasting, due to the nature of the input data used to calculate the future income of the population of Khmelnytsky region. Using this systematic approach to management tasks can not only improve the decision-making process for the management of sustainable development of the region, but it also allows you to optimize the organizational structure of the economic system the region.

\section{Problem Solution}


Thus, sustainable development, in the general sense, is a development that meets the needs of the current generation without harming future generations. That is, the integration of economic and environmental interests of society is the basis for sustainable development not only of the business entity, but also of the region as a whole. Disturbance of balance between them influences deterioration of quality of life and well-being of the population of region.

V.S. Zagorskyi defines it as "the process of harmonization of productive forces, ensuring the satisfaction of the necessary needs of all members of society while preserving and gradually reproducing the integrity of the environment, creating opportunities for balance between its potential and the needs of people of all generations" [16,p. 59]. D.Lvov considers sustainable development in two meanings, that is "narrow" and "broad", as environmental sustainability and all other types of sustainability (demographic, economic, social, manmade, etc.), respectively $[17,18]$.

Therefore, the basis of sustainable development should be the equality of relations in the triangle "person - business entity - nature". However, a person is the central link in environmental and economic relations. As an active participant and as the only representative of the natural and management system, a person can avoid the uncoordinated use of ecosystem elements.

This idea of combining economic and social aspects of ecologically sustainable development within a single ecological and economic system provides new methodological approaches to the study of socio-economic development of the region. We will reveal this dependence by modeling the living standards of the population in the Khmelnytskyi region in the projection on the level of solid waste use.

Thus, 11-13 million tons of solid household waste (hereinafter, SHW) are generated annually in Ukraine. The annual amount of waste per capita is about $300 \mathrm{~kg}$, with a significant difference in waste generation between urban and rural areas. The increase in waste generation is associated with an increase in living standards, given the relationship between the dynamics of SHW per capita and the levels of specific waste generation. According to various data, the level of solid waste processing in Ukraine ranges from 3 to $8 \%$, while for the European Union countries it is up to $60 \%$ of solid waste. At the same time, more than $90 \%$ of solid waste is sent to landfills and unauthorized landfills. According to official estimates, 10000 hectares of land are occupied by about 6700 landfills and dumps, although unofficial figures may be even higher. However, according to the Ministry of Regional Development, Construction and Housing of Ukraine, there is a need for at least 626 new solid waste landfills [10].

In addition to occupying land plots, such landfills emit greenhouse gases and pollutants that enter the atmosphere, surface soil layers, groundwater and subsoil. This negatively affects flora and fauna, as well as reduces the quality of life in nearby residential areas. The lack of separate collection and disposal of waste containing toxic components increases the risk of environmental pollution by hazardous substances.

In order to demonstrate the dependence of the motivation of the population of the region to sort household waste from its financial situation and analysis of the state of environmental management of the region, we should consider data on economic well-being of Ukraine as a whole and the region in particular.

It is necessary to analyze the distribution of the population by the level of per capita equivalent total income. Compared to 2017 by 2018 the number of people with incomes over UAH 5160 increased compared to the previous year by $14.2 \%$. The number of people receiving income from UAH 4800 to UAH 5160 increased by $1.8 \%$. This indicates an increase in the number of high-income people by $12.1 \%$ in 2018 [13].

Total resources are higher than total household expenditures. We compared indexes in 2010, when the savings were UAH 407.7 per household. The most significant year for households was in 2015, where the savings amounted to only UAH 279.7, but in 2018 the savings amounted to UAH 1595.

Therefore, it is necessary to analyze the average level of wages in Ukraine. Starting from 2014 the level of wages was increased by UAH 6542 [10]. Also, the subsistence level in the country is growing every year. Thus, the level of wages and total income and expenditure is growing every year, and logically, the higher the income of the population, the greater the expenditures of one household as a whole.

We decided to analyze these indicators in the Khmelnytsky region to prove the above statement, and therefore to develop appropriate recommendations for environmental management in this region.

In the process of building an adequate model, we made more than twenty iterations, so we chose a model that met the econometric and market conditions, namely the model was tested for 
adequacy according to the criteria of Fisher and Sudent.

So table 1 presents the input data for modeling the income of the population of Khmelnytsky region, which are the main factors influencing the resulting indicator. This dependence is clearly shown in Fig.1.

These factors have the closest connection and direct relation to the resulting indicator. Therefore, these indicators fall under the following econometric transformations.

Table 1 - Input data for the simulation process

\begin{tabular}{|c|c|c|c|c|c|}
\hline Years & $\begin{array}{l}\text { Total } \\
\text { income for } \\
\text { the year } \\
\text { (thousands, } \\
\text { UAH) } Y\end{array}$ & $\begin{array}{l}\text { Gross } \\
\text { value } \\
\text { added } \\
\text { (UAH } \\
. \text { ) } \\
x_{I}\end{array}$ & $\begin{array}{l}\text { Fixed } \\
\text { capital } \\
\text { investmen } \\
\mathrm{t} \text { (in actual } \\
\text { prices, } \\
\text { UAH, } \\
\text { million) } x_{2}\end{array}$ & $\begin{array}{l}\text { The } \\
\text { averag } \\
\text { e } \\
\text { month } \\
\text { ly } \\
\text { salary } \\
\text { of an } \\
\text { emplo } \\
\text { yee in } \\
\text { the } \\
\text { region } \\
\text { (UAH } \\
\text { ) } x_{3}\end{array}$ & $\begin{array}{l}\text { Gross } \\
\text { regional } \\
\text { product } \\
\text { at actual } \\
\text { prices } \\
\text { (thousan } \\
\text { ds, } \\
\text { UAH) } x_{6}\end{array}$ \\
\hline 2014 & 2145667 & 18262 & 205131.5 & 3030 & 26426 \\
\hline 2015 & 3547783 & 22063 & 224463.1 & 3418 & 32162 \\
\hline 2016 & 4595691.02 & 27806 & 189096.9 & 4326 & 41088 \\
\hline 2017 & 5386882.1 & 33316 & 165530 & 5315 & 48859 \\
\hline 2018 & 3964683.01 & 42652 & 158158.3 & 7559 & 63882 \\
\hline 2019 & 8582191.8 & 48365 & 170764.1 & 8976 & 68354 \\
\hline
\end{tabular}

Figure 1 shows a visual representation of the forecast of total income for the year according to the statistics of the Khmelnytsky region for 2014-2019.

Total income for the year (thousand UAH) Y

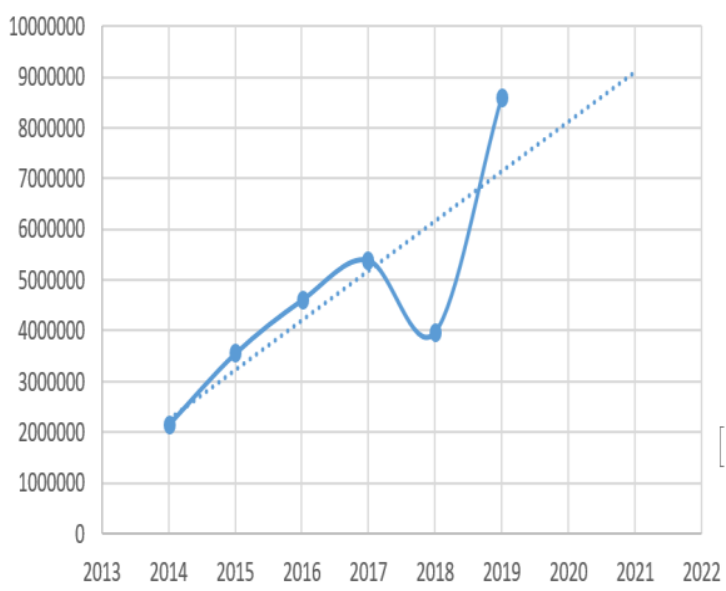

Figure 1 - Dynamics of total incomepopulation of Khmelnytsky region and its forecast
Therefore, the resulting indicator tends to increase. According to statistics, there is an increase in total income of the region (curved line). It should be noted that the total income for the year includes all United Territorial Communities (UTC) of the region and the city of Khmelnytsky. The forecast of incomes of the population for the next two years in the region presented by us is given by linear dependence. Thus, it is clear that the annual increase in this indicator is a positive trend for the region, which in the future, according to forecasts, will also continue.

Thus, as a result of calculations, we can write down the econometric model constructed by us:

$$
Y=368228-2450,45 x_{1}+6,07 X_{2}-3005,05 x_{3}-1175,44 x_{4}(1)
$$

From the obtained model we can conclude that most indicators are inverse but the parameter $\mathrm{x}_{2}$ is directly dependent. According to the conditions of the method, we can build a forecast value of total income for the year to determine the standard of living in the future.

Table 2 - Actual and forecast value of $Y$

\begin{tabular}{|l|l|l|}
\hline Years & $\begin{array}{l}\text { Total income } \\
\text { for the year } \\
Y\end{array}$ & Forecast $Y$ \\
\hline 2014 & 2145667 & 2145838.161 \\
\hline 2015 & 3547783 & 3669102.629 \\
\hline 2016 & 4595691.02 & 4306824.648 \\
\hline 2017 & 5386882.1 & 5559446.161 \\
\hline 2018 & 3964683.01 & 3990201.275 \\
\hline 2019 & 8582191.8 & 8551485.056 \\
\hline
\end{tabular}

Thus, according to the obtained forecast values, you can build a graph comparing the actual values and forecast. 


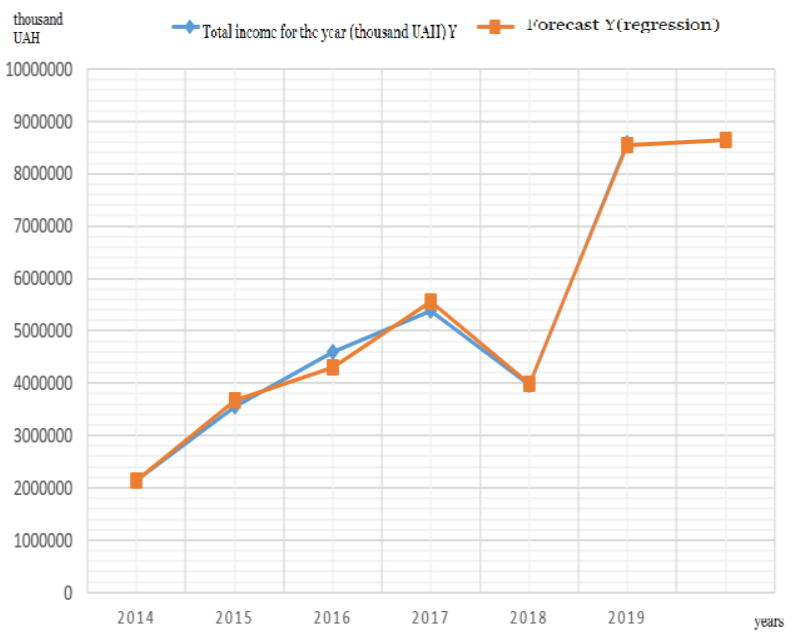

Figure 2 - Comparison of actual $\mathrm{Y}$ value and forecast $\mathrm{Y}$

Thus, the value of total income in the region increases. If we increase the value by one $\%$, then in the future the resulting figure will increase, i.e the general trend is to increase the total income of the Khmelnytskyi region, it will increase by 54808.1 thousand UAH. The trend model for determining the standard of living of the population is as follows:

$Y=-3682238-2450,46 x_{1}+6,071 x_{2}-3015,05 x_{3}-1075,44 x_{4}$

The found value of the correlation coefficient $R$ is 0.98 indicates a tight direct relationship between the performance indicator and the time factor.

The coefficient of determination $R^{2}$ is equal to 0.78 , which means that the variation of the dependent variable of the total income is due to the influence of the time factor, so you can use the resulting regression model for forecasting. This figure shows that $98 \%$ variation in total income is a variation of the time factor and $0.2 \%$ is due to other factors, and the high value of the standard error 359909.3 indicates a small number of conducted observations. The calculated value of Fisher's criterion $F p$ is 2.38 less than its tabular value ( $F$ tabl is 13), therefore, according to the constructed model (2) it can be taken as valid. That is, this model is adequate and meets market conditions.

Therefore, for the convenience of observation it is necessary to build a graphical expression of the obtained model.

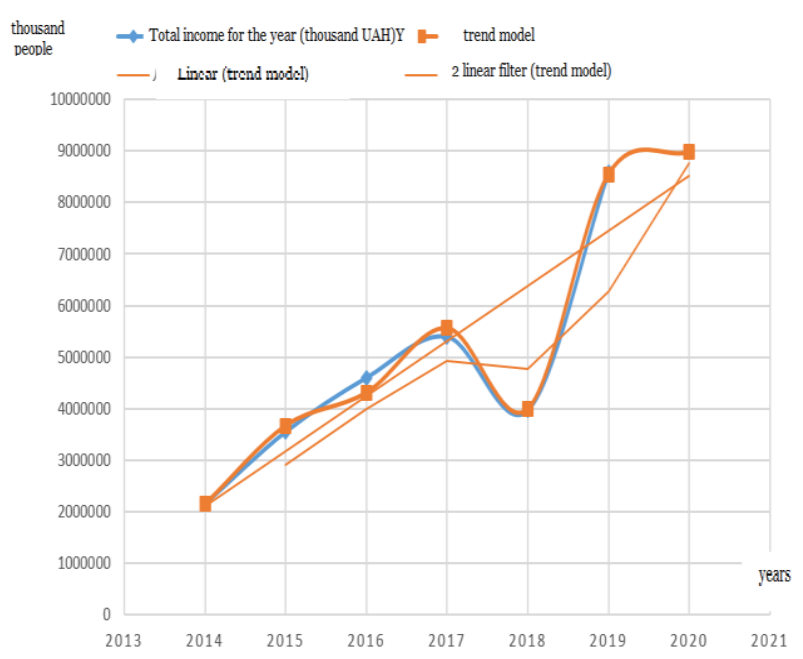

Figure 3 - Construction of a trend model of total income for the period from 2014 to 2020

Figure 3 shows the econometric expression of the obtained results of the trend model. Among the most commonly used in macro- and microeconomic research types of dependences that describe the equation of the trend (additive models -parameters are estimated by the method of least squares; linear; logarithmic; hyperbolic, multiplicative -which are reduced to additive by logarithmic predictions, we chose the model for .

Thus, we have carried out a number of econometric transformations, received econometric models that can determine the standard of living in the region. We chose the factors influencing the resulting indicator, checked the obtained models for adequacy, and determined that they meet market conditions. According to the obtained models, it is possible to determine that the standard of living in the region will grow, and in order to see for yourself this it is necessary to build forecast models of living standards in the Khmelnytskyi region.

We used the built-in linear function in Excell "Forecast". We calculated and predicted our future value using existing values. The future value in our case, the value of income is the value of $y$ for a given value of $\mathrm{x}$. Existing values are known values of $\mathrm{X}$ and $\mathrm{Y}$, and future values are predicted by linear regression. This feature can be used to predict future revenue values or other economic indicators. 
Table 3 - Obtained forecast values of the resulting indicator using the built-in linear function in Excell "Forecast"

\begin{tabular}{|l|l|l|l|l|l|}
\hline Year & $x_{j}$ & $y_{j}$ & Forecast & $\begin{array}{l}\text { The } \\
\text { minimum } \\
\text { value of the } \\
\text { forecast } \\
\text { value }\end{array}$ & $\begin{array}{l}\text { The maximum } \\
\text { value of the } \\
\text { forecast }\end{array}$ \\
\hline 2014 & 0 & 2145667 & 2145667.00 & 2145667.00 & 2145667.00 \\
\hline 2015 & 1 & 3547783 & 3547783.00 & 3547783.00 & 3547783.00 \\
\hline 2016 & 2 & 4595691 & 4595691.02 & 4595691.02 & 4595691.02 \\
\hline 2017 & 3 & 5386882 & 5386882.10 & 5386882.10 & 5386882.10 \\
\hline 2018 & 4 & 3964683 & 3964683.01 & 3964683.01 & 3964683.01 \\
\hline 2019 & 5 & 8582192 & 8582191.80 & 8582191.80 & 8582191.80 \\
\hline 2020 & & & 7944226.907 & 5773858.711 & 10114595.1 \\
\cline { 1 - 4 } 2021 & & & 8910758.498 & 6740380.535 & 11081136.46 \\
\cline { 5 - 7 } & & & &
\end{tabular}

For the best visualization of the received results we will construct the graph.

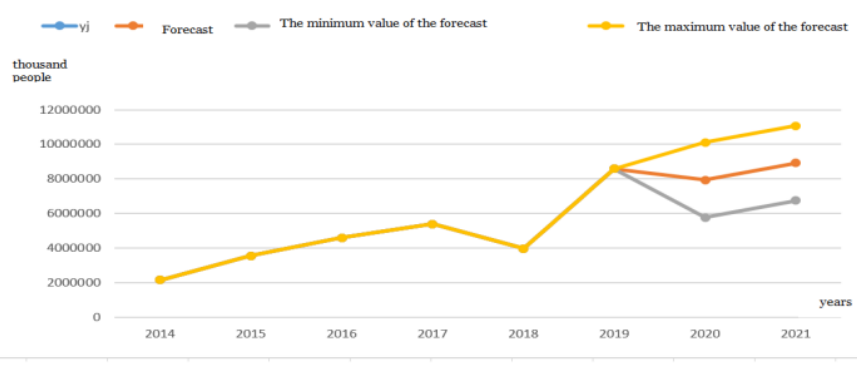

Figure 4 - Construction of a forecast model for the built-in "Forecast" function for the period from 2014 to 2020.

This method indicated that the resulting indicator will increase by a maximum of UAH 2498944.66, and may decrease by minus UAH 1841811.26.

The next built-in Excell function is "FORECAST". According to the conditions of this function, the forecast is based on the future period as a linear value.

Table 4 - Obtained predictive values of the resulting indicator using the built-in "FORECAST" function

\begin{tabular}{|l|l|l|l|l|l|}
\hline Years & $\mathrm{y}_{\mathrm{j}}$ & $\mathrm{X}_{1}$ & $\mathrm{X}_{2}$ & $\mathrm{X}_{3}$ & $\mathrm{X}_{6}$ \\
\hline 2014 & 2145667 & 18262.00 & 205131.5 & 3030.00 & 26426.0 \\
\hline 2015 & 3547783 & 22063.00 & 224463.1 & 3418.00 & 32162.0 \\
\hline 2016 & 4595691.02 & 27806.00 & 189096.9 & 4326.00 & 41088.0 \\
\hline 2017 & 5386882.1 & 33316.00 & 165530.0 & 5315.00 & 48859.0 \\
\hline 2018 & 3964683.01 & 42652.00 & 158158.3 & 7559.00 & 63882.0 \\
\hline 2019 & 8582191.8 & 48365.00 & 170764.1 & 8976.00 & 68354.0 \\
\hline 2020 & 2170368.20 & 54813.22 & 128688.3 & 10259.86 & 80843.9 \\
\hline
\end{tabular}

For a better view of the received results we will build a graph.

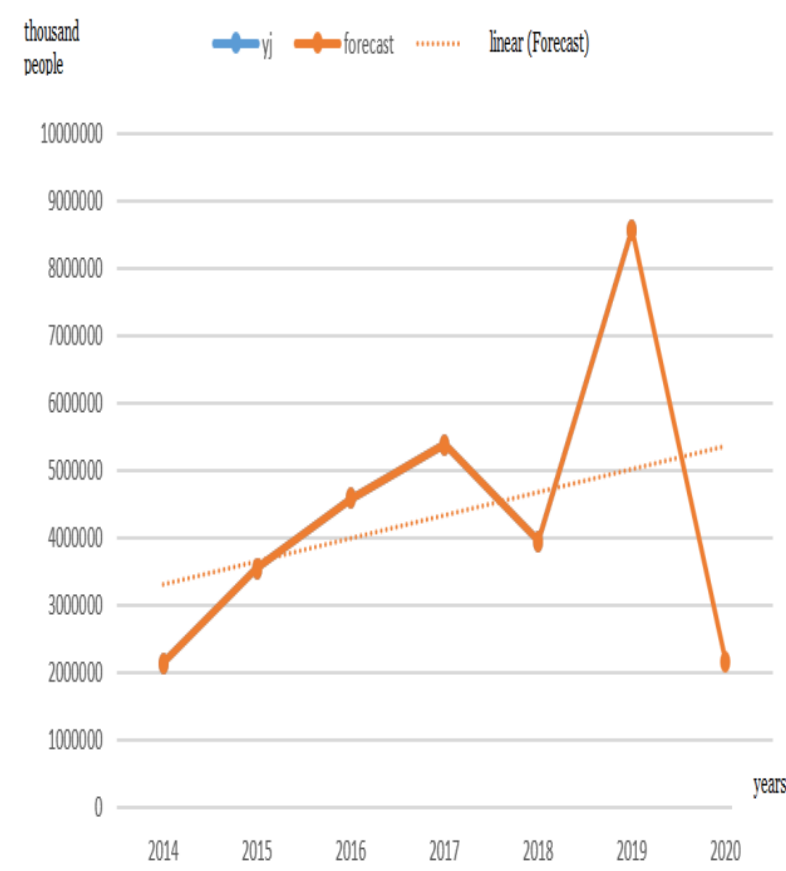

Figure 5 - Construction of a forecast model with the built-in "FORECAST" function for the period from 2014 to 2020.

According to this method, we can observe that the forecast value will be negative, and the value of the resulting standard of living will decrease in 2019 by $6411823.60 \mathrm{UAH}$.

You should also use another built-in Excell function to obtain the predicted value of living standards, which is the "Trend" function.

Table 5 - The predicted values of the resulting indicator using the built-in function

\begin{tabular}{|l|l|}
\hline Years & Predicted $Y$ \\
\hline 2014 & 2145667 \\
\hline 2015 & 3547783 \\
\hline 2016 & 4595691 \\
\hline 2017 & 5386882.1 \\
\hline 2018 & 3964683 \\
\hline 2019 & 8582191.8 \\
\hline 2020 & 8126268 \\
\hline
\end{tabular}


For a better picture of the above results, you should build a graph.

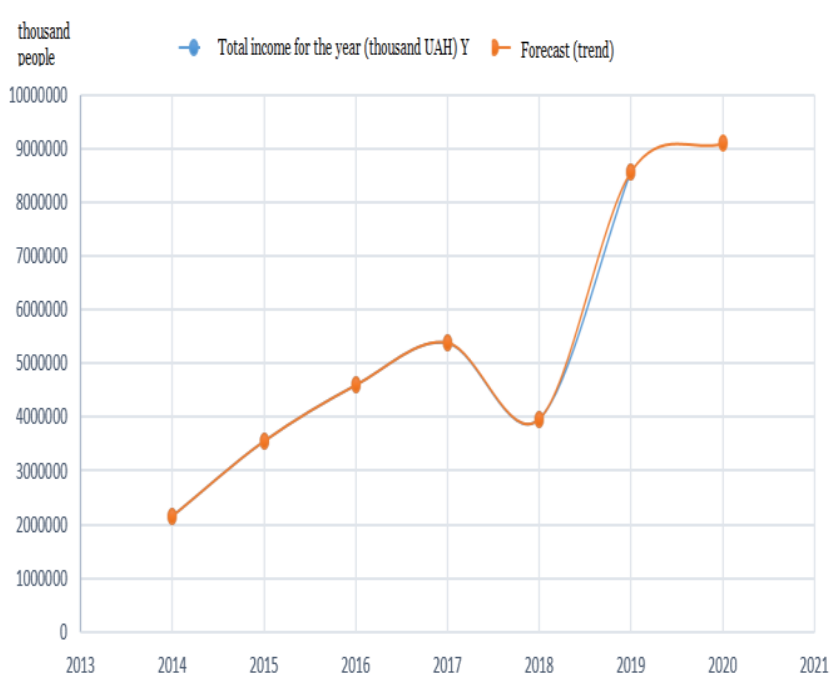

Figure 6 - Construction of a forecast model with the built-in "Trend" function for the period from 2013 to 2019.

As can be seen from Picture 5, this function, as well as the previous ones, indicated a significant decline in the resulting indicator, a decrease of UAH 455923.96.

Thus, it is necessary to present all the obtained models and forecast models that were built using economic and mathematical modeling. Also, we additionally calculated the forecast values of living standards of the Khmelnytskyi region population using the method of the average group point (AGP) and the method of two extreme points (TEP), and also we added other linear forecasts shown in the figure.

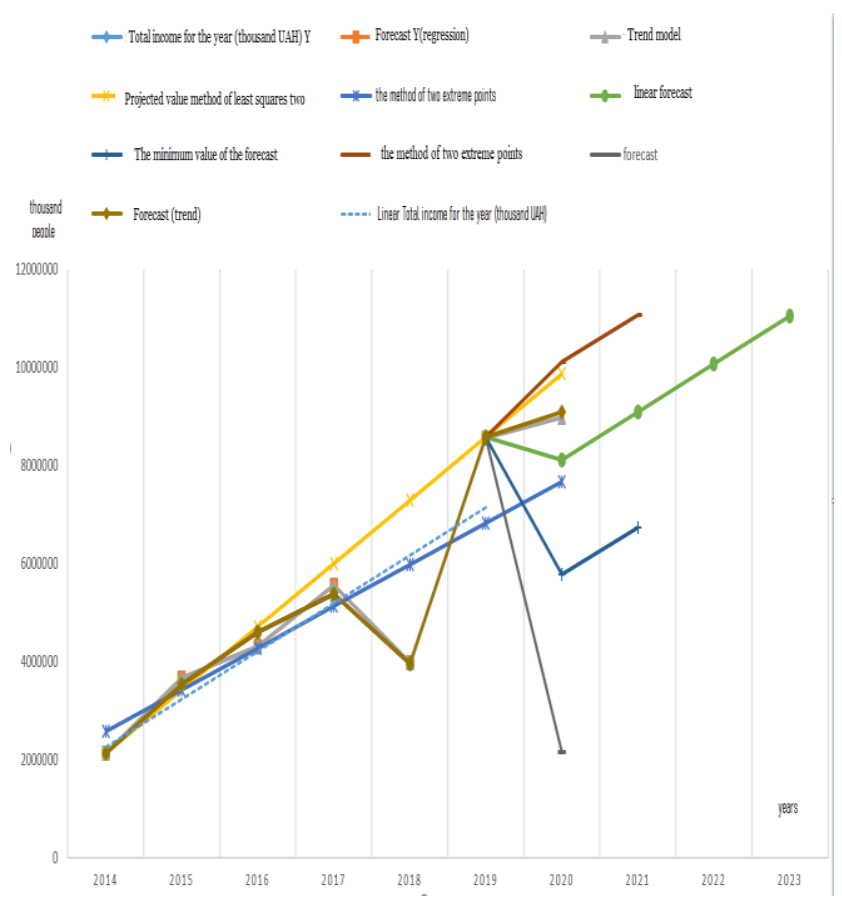

Figure 7 - Comparison of all constructed models of the resulting indicator

Ttherefore, we note that the level of sustainable development of the region is a rather complex phenomenon. The interdependence of natural, socioeconomic, industrial, demographic factors is difficult to analyze due to their dynamism, and often due to high dependence on the political factor, which has a direct impact on the environmental management system of the region. Therefore, to talk about the sustainability of the region means to talk about its competitiveness that is preservation of its industrial, economic and organizational structure, preservation of its natural environment and increasing living standards, etc., for a long time period.

\section{Conclusion}

So, summarizing the above above-mentioned, it should be noted, that in the article we submitted the following conclusions :

1) The economic condition of the Khmelnytsky region is analyzed. However, despite the positive indicators of income growth in the region, forecasting for future periods is not such a positive trend. The economic and political situation in the country caused a decline in incomes in the region over the next two years.

Based on this, the modeling of living standards in the Khmelnytskyi region allowed us to trace the dynamics of change in future periods. According to these calculations, the decline in living standards in 
the region is expected. This calculation is probably more accurate than previous forecasts for improving living standards in general. The main impact on the decline in the region's living standards was certainly caused by the pandemic and measures with negative economic consequences for its prevention, such as lockdowns and quarantines, introduced by the government since March 2020.

2) For this forecast, we have selected the main indicators presented by $\mathrm{Y}$ and $\mathrm{X}$, respectively - total income for the year, gross value added, fixed capital investment, average monthly salary of an employee in the region, gross regional product at actual prices. Based on them, a number of models of living standards of the region's population were built and these models were tested for adequacy and compliance with market conditions.

Characteristic of the Khmelnytskyi region is that enterprises of medium and small businesses and incomes of physical persons - entrepreneurs are the basis of its economy. As there was no clear incentive and support for this sector, the losses and damages incurred by them had a negative impact not only on the economic condition of the region, but also on the environmental one.

3) The calculations allowed us to confirm the basic position on the dependence of the level of ecological status of the region on its economic condition. In other words, the higher the standard of living of the population of any region, the more conscious and responsible is the population in addressing the issue of household waste, and hence the environmental development of the region.

Khmelnytskyi region is the first region to join the full-scale project on waste sorting, and starting in 2018, sorting stations began to be installed in the city and the region. However, as evidenced by modeling, waste sorting, and therefore the level of environmental management of the region still depends on the standard of living of its population. And with the reduction of incomes of the population of the region, the purposefulness and use of them as well as the uniformity of consumption decrease. The shift of consumption from the non-food sector to the food sector for the population causes the zero need to sort household waste. Thus, there is a violation of parity in the triangle "person - business entity nature" where a person with his or her standard of living, forms the economy of ecological development of the region. And for the Khmelnytskyi region data, such a simulated indicator is not comforting.

To maintain parity in the classic model of sustainable development of the region, we can offer a classic model for solving the problem of waste - the construction of recycling plants. This will primarily contribute to ensuring the proper sanitary and epidemiological level of the region, as well as increasing the economic condition and welfare of the region's population through: - growth of jobs and businesses themselves, such as waste recycling; formation of adequate tariffs for communal services for garbage removal, which will save the local budget and the population of the region; - formation and use of alternative energy sources obtained from waste processing; - growth of the investment climate in the region.

4) Checking the model for adequacy, proving the compliance of regression and trend models with market conditions makes it possible to use them in forecasting living standards in any region. At the same time factor changes can change, the resulting indicator can remain invariable. Determining the probable value of the resulting indicator will make it possible to determine the standard of living of the region's population, which will help to develop a forecast for the sorting of waste for individual households and the region as a whole. Thus, the higher the household income, the higher the quality of life of the population. And we can talk about the development of the region in the context of its sustainability.

\section{References:}

[1] Kabir Z., Morgan R. K. Strategic environmental assessment of urban plans in New Zealand: current practice and future directions. Journal of Environmental Planning and Management, 2021, 64(6), 954-977

[2] Kocmanova A., Hornungova J, Docekalova M. Sustainable Corporate Performance: Interaction between Environmental, Social, Corporate Governance and Economic Indicators. Int. J. of Applied Mathematics, Computational Science and Systems Engineering, 2020, 2, 113-121

[3] Yanling $\mathrm{Ma}$ Research on the Coupling Coordinative Degree of Tourism Development and Poverty Alleviation Effects in China based on the Model of DPSIR-An Example of Guizhou. International Journal of Circuits, Systems and Signal Processing, 2020, 14, 637-645

[4] Chu Fangfang and Jiang Difei. Evolutionary tendency of ecological-economic system in chang-zhu-tan city cluster based on emergy analysis. Economic geography, 2012,32(02),143-148.

[5] Ovchynnikova O., Dupliak O., Khan O. Modelling and forecasting of the region's 
environmental indicator. The International Conference on Sustainable Futures: Environmental, Technological, Social and Economic Matters (ICSF 2020). E3S Web of Conferences, 2020166, $13004 /$ doi.org/10.1051/e3sconf/202016613004

[6] Guerrero, A. M., N. J. Bennett, K. A. Wilson, N. Carter, D. Gill, M. Mills, C. D. Ives, M. J. Selinske, C. Larrosa, S. Bekessy, F. A. Januchowski-Hartley, H. Travers, C. A. Wyborn, and A. Nuno. Achieving the promise of integration in social-ecological research: a review and prospectus. Ecology and Society 2018,23(3):38. doi.org/10.5751/ES10232-230338

[7] Heyets V., Voynarenko M., Dzhedzhula V., Yepifanova I. \& Trocikowski T. (2021) Models and strategies for financing innovative energy saving activities, IOP Conf. Series: Earth and Environmental Science, 628, 012004, doi:10.1088/17551315/628/1/012004

[8] Mamatova T.V., Chykarenko I.A., Moroz E.G., Yepifanova I.Y., Kudlaieva N.V. Management of enterprises and organizations under the conditions of sustainable development. International Journal of Management, 11(4), 2020, pp. 151-159

[9] Willemse Marinél, Goble Bronwyn J.. A Geospatial Approach to Managing Coastal Access in KwaZulu-Natal, South Africa. Journal of Coastal Research, 2018,34 (2), 282292.

[10] Hilorme, T., Zamazii, O., Judina, O., Korolenko, R., Melnikova, Y. Formation of risk mitigating strategies for the implementation of projects of energy saving technologies Academy of Strategic Management Journal, 2019, 18(3)

[11] Voynarenko M, Dzhedzhula V., Hurochkina V., Yepifanova I., Menchynska, O. (2021). Applying Fuzzy Logic to Modeling Economic Emergence WSEAS Transactions on Business and Economics, 18, 424-433.

[12] Ukraine after 2015: The future we strive for: nat. ext. / [Libanova EM, Balakireva OM, Ermolaev AV and others]. URL : http://www.ua.undp.org/content/dam/ukraine/d ocs/PR/ Post\%202015\%20Ukraine\%20ukr.pdf.

[13] State Statistics Service of Ukraine. URL: http://www.ukrstat.gov.ua.
[14] Ukraine after 2015: The future we strive for: nat. ext. / [Libanova EM, Balakireva OM, Ermolaev AV and others]. URL : http://www.ua.undp.org/content/dam/ukraine/d ocs/PR/ Post\%202015\%20Ukraine\%20ukr.pdf.

[15] Sustainable Development Goals 2016 - 2030 URL : http://www.un.org.ua/ ua/tsili-rozvytkutysiacholittia/tsili-staloho-rozvytku.

[16] Zagorsky V.S. Z Kontseptualni osnovy formuvannya sistemy upravlinnia stalim rozvytkom ekologo-ekonomichnykh system [Text]: monograph - Lviv: LRIDU NADU, 2018. - 336 p.

[17] Lvov D.S. The way to the XXI century: strategy, problems, prospects of the Russian economy. M .: Ekonomika, 1999. 168 p.

[18] Lvoiv D. Economics of development. M .: Ekzamen, 2002. p.

\section{Contribution of individual authors to the creation of a scientific article (ghostwriting policy)}

Olha Dupliak carried out the simulation and the optimization, systematization of influencing factors, description of results and implemented of econometric models

Oksana Zamazii processed statistical information and identified the main factors of influence. Described the analytical part of the selected factors. Vitalii Karpenko was responsible for the Statistics and Literature.

Oksana Proskurovych checked the obtained models for adequacy and described the market characteristics.

Andrii Mazarchuk worked out methods and existing models also influencing the resulting indicator.

\section{Creative Commons Attribution License 4.0 (Attribution 4.0 International , CC BY 4.0)}

This article is published under the terms of the Creative Commons Attribution License 4.0 https://creativecommons.org/licenses/by/4.0/deed.en US 